\title{
Social and Digital Accountability of Provincial Government of Jakarta in Tackling Covid-19 Pandemic
}

\author{
Adi Suryanto* \\ Chairman of NIPA \\ Indonesia \\ *adi.suryanto@lan.go.id
}

\author{
Nurliah Nurdin \\ Director of NIPA School of Administration \\ Indonesia \\ nurliah.nurdin@stialan.ac.id
}

\author{
Ohan Suryana \\ Student of NIPA School of Administration \\ Indonesia \\ ohansuryana3@gmail.com
}

\begin{abstract}
The corona virus pandemic which was occurred in 2019 in Wuhan, China has spread global fear. All governments have responded differently in tackling the virus, from local to central government. Earlier, Indonesian Government underestimated the Covid-19 that the virus would not touch the land. However, province Jakarta distinguishingly realized and acted profoundly to prevent as well as to prepare for the worst scenario of pandemic Covid 19. Jakarta shows the spread of the virus as social accountability. Covid 19 Pandemic presents challenges for civil society such as asymmetry power between executive and accountability mechanisms, however, there are also new opportunities for it to embrace digital civic engagement. Online collaboration for social accountability emerged during the pandemic. Establishing digital accountability networks to support this effort is a demand for developed urban society. Applying the concept of social accountability along with digital accountability, this study promoted a model of new leadership by using a content analysis method.
\end{abstract}

Keywords—social, digital, accountability, pandemic covid 19, jakarta local government

\section{INTRODUCTION}

The Covid 19 disease outbreak first occurred in Wuhan China in December 2019. The World Health Organization (WHO) on March 112020 announced the status of the Covid 19 Pandemic. This was due to the threefold increase in positive cases outside China in 114 countries with a total of 4,291 deaths at that time. WHO asks countries around the world to take firm and aggressive preventive and control measures for the COVID-19 virus [1]. Currently, the cumulative total of COVID-19 cases worldwide is $27,236,916$ with a case fatality rate (CFR) of $3.28 \%$. A total of 215 countries in the world are affected by Covid 19.5 countries with the highest cumulative total cases, namely the United States $(6,222,974$ people), India
(4,280,422 people), Brazil $(4,137,521$ people), Russia (1,035,789 people), and Peru (689,977 people) [2].

Not a single country in the world is ready to face the COVID-19 pandemic. Even a superpower like the United States accounts for the highest number of cases in the world at this time.However, there are several countries that can deal with the Covid 19 virus attack well enough so that it can minimize the morbidity and impact due to Covid-19. For example, New Zealand and South Korea which are recognized by WHO have exemplary strategies in dealing with the Covid19 pandemic. The strategy has been undertaken by the New Zealand Government is by early regional quarantine accompanied by massive testing and tracing [3].

South Korea does not implement a regional lockdown, but handling it by an IT-based system for geotagging and geolocation features to track user location history and provide notifications to people who have been in contact with or are near corona patients in addition to CCTV and credit card transactions and cell phone tracking. South Korea also implemented mass tests which were carried out quickly and safely. Every day a total of 20,000 tests are conducted using the drive-through method so that people do not have to get off their respective vehicles [4]. The strategy is to increase public participation and transparency.

When compared with countries that have successfully weathered the crisis due to Covid 19 such as New Zealand and South Korea, Indonesia is still far from success. Since the beginning of the announcement of the Covid 19 Pandemic, the Indonesian government has tended to underestimate and deny that the Covid-19 virus can hit Indonesia. In fact, when other countries in the world went into lockdown, Indonesia instead opened tourism with a policy of discount airline tickets and exemption from hotel and restaurant taxes [5]. 
Earlier in January and February, the Central Government seemed unprepared in preventing and handling and spreading this virus. The prediction from Harvard University which claimed that Covid-19 had arrived in Indonesia was rejected. Officials and elites tend to underestimate and imply that Indonesians are immune to the covid 19 virus attacks [6]. For example, they said the corona such as "Diphtheria, we are not afraid, let alone corona", "Flu is more dangerous than the coronavirus", "Masks for sick people" [7]. Central government only acknowledged the virus since March 2, for two infected cases, after that it only used Health Alert Cards or Yellow Cards and Thermal Scanners to check body temperature above 38.5 degrees Celsius. This is of course less effective because filling in the Yellow Card requires honesty from the filler and also when entering the incubation period, the symptoms of Covid 19 do not immediately show symptoms of fever but can transmit the virus to other people [8].

In contrast, the Governor of DKI Jakarta, from the beginning has monitored the development of the Covid-19 case and held a closed meeting on January 29, 2020 by inviting immigration and the State Intelligence Agency to discuss the threat of the Covid-19 case. The intention was to monitor the presence of Indonesian citizens or foreigners who have just arrived from abroad, and immediately prepare all the worst possibilities [9]. Even, the DKI Jakarta Government through letter No. 143 dated 28 March 2020 made a request to the central government regarding the quarantine of the DKI Jakarta area, but the request was rejected by the Central Government [10]. Unfortunately, as of August 30 2020, the cumulative total of COVID-19 cases in Indonesia reached 172,053 cases. DKI Jakarta is the province with the highest cumulative figure. There were 37,761 cases of Covid-19 in DKI Jakarta, followed by East Java (33,205 cases), Central Java (13,785 cases), South Sulawesi $(11,870$ cases $)$, and West Java $(10,819$ cases $)$ as 5 provinces with 19 cases of Covid [11].

Social accountability to answer the doubt and anxiety of citizens through digital government has been implemented by the Jakarta Government. They have been collaborated with students who are currently studying at Harvard University developed the Covid-19 Likelihood Meter (CLM). CLM functions to calculate a person's risk factors so that they can help the government assess a person's eligibility for a rapid test. In addition, through the Jakarta Aman application, there is a feature for reporting for residents exposed to Covid 19. The DKI Jakarta Government is also collaborating with Sekolah.mu which provides digital learning materials that can be accessed by teachers and students. Further, working with Nodeflux to build a monitoring system using Artificial Intelligence (AI). This AI monitoring system can detect and calculate the density of people and vehicles (Public Mobility Monitoring), monitor and give warnings automatically when the distance between humans is less than 1 meter (Social Distance Monitoring), and monitor and give warnings automatically when there are residents who are not wearing a mask (Face Mask Monitoring) [12].
However, still many non-governmental organizations (NGOs) are demanding that the government take Covid 19 more seriously. The Civil Society Coalition consisting of the Indonesia Corruption Watch (ICW), Indonesia Budget Center (IBC), the National Secretariat of the Indonesia National Forum for Transparency and Transparency International Indonesia in its report states that the problem of the spread of covid that continues to increase in Indonesia is due to, among others, inconsistency in policies being implemented, lack of transparency and poor coordination between one another, especially between institutions and between the center and the regions [13].

Civil society organizations consisting of the Indonesian Legal Aid Foundation (YLBHI), LBH Jakarta, the Urban Poor Consortium, the Lokataru Foundation, the Rujak Center for Urban Studies and the Amrta Institute for Water Literacy organized independent complaints via Whatsapp. As of May 11 , there were 254 complaints received from 12 provinces in DKI Jakarta, West Java, Central Java, East Java, Banten, DIY, North Sumatra, South Sumatra, Bali, North Sulawesi, South Sulawesi and NTT. Complaints regarding the distribution of social assistance were dominated by residents of DKI Jakarta with $32 \%$ of the total complaints or there were 71 reports. Furthermore, there were 28 complaints about social assistance from residents of West Java and 9 reports from Banten [14].

ICW and IBC received 12 citizen reports regarding covid 19 social assistance. Seven reports contained complaints about the reduction of social assistance packages, one report that residents received more than once, and four reports of residents claiming not to receive them even though they were registered as recipients. Meanwhile, based on the monitoring carried out by ICW and IBC in a number of media from social assistance stage one to stage four, there are at least five cases of suspected Covid-19 social assistance abuse in DKI Jakarta. The number is divided into five categories of cases. Category one case is in the form of illegal fees; two cases of reduction; and two cases of wrongly targeted social assistance. So that the total number of allegations of social assistance deviation from both media reports and citizen reports was seventeen cases [15].

The Covid 19 pandemic indeed demands government transparency in its tackling, considering the enemies we are currently facing require us to keep our distance and minimize meetings. Social accountability for people who are directly affected by the pandemic and Digital Accountability as a form of transparency and communication between the government and the community in handling Covid 19 are very important

Considering the urgency of accountability both socially and digitally by the government, especially the DKI Jakarta provincial government as a contributor to the highest cumulative number of cases as well as the capital of Indonesia. The paper examines the social and digital accountability of the provincial government of Jakarta in tackling Covid-19 pandemic. The paper explains social and digital accountability by analysing three approaches: engaging people; establishing 
multi stakeholders partnership; and accelerating implementation of innovation digital technology.

\section{METHODS}

This study used content analysis as a qualitative analysis which based on written analysis, verbal, or visual documentation using media online. Content Analysis used in this study is to analyze news, websites, articles, policy briefs and journals related to the social and digital accountability of the DKI Jakarta provincial government in dealing with covid19 in DKI Jakarta. Further more, the study also compares with other provinces in Indonesia in dealing with Covid-19 in their regions. The research has used online media and official websites to analyze the realities related to people's engagement in tackling Covid 19 pandemic, in endorsement of stakeholder partnership and implementation of digital technology.

Content is analyzed by breaking it up into conceptual chunks that are then coded or named. Qualitative analysis develops the categories as the analysis takes place. The results are used to make inferences about the messages in the text [16]. Content analysis is valuable in organizational research because it allows researchers to recover and examine the nuances of organizational behaviors, stakeholder perceptions, and societal trends only by having secondary data [17].

Considering the pandemic, primary qualitative method by interview, focus group discussion, observation were difficult to apply due to social and physical distancing. It is also an important bridge between purely quantitative and purely qualitative research methods.

\section{RESULTS}

The study has formulated three factors that could determine social and digital accountability of Jakarta Government in tackling pandemic covid, they are engaging people, stakeholders collaboration and implementation of digital technology.

\section{A. Engaging People}

The Pandemic has changed the way citizens behave socially in which they have to make social distancing, no guess at home, no visiting relatives and friends, no gathering, no religious activities at the masjid, church, pura. Citizens were keeping away from their social life. The situation becomes more difficult by regulation of large scale social distancing (PSBB). By September 11, positive covid in Jakarta reached 50.671 with 1.351 deaths [18]. PSBB has been applied three times since the first case. Originally, the transitional PSBB was held for 28 days or from 5 June to 2 July 2020. However, it was extended again by 14 days until 16 July 2020. The PSBB transition extension 1 all activities were still the same as when the first time a transitional PSBB was carried out, namely 50 percent. The transitional PSBB was extended after the DKI Pemprov looked at scores on three elements, namely epidemiology, public health, and public facilities. The score for these three elements, namely 71 , qualifies for the loosening.
The governor, Anies Baswedan decided that the transitional PSBB was extended for 14 days.

The form of assistance to others during the Covid-19 pandemic was also provided in the form of food distribution. Conducting the "Free Meal Operation with 1,000 Warteg" in the Greater Jakarta area to provide ready-to-eat food assistance every day, running a free rice program for underprivileged residents with a target number of 100,000 households [19].

Responding to various problems arising from the outbreak of Covid-19 in DKI Jakarta, The Governor issued a policy by inviting all levels of society to help each other institutions or social units affected by Covid-19. The policy is implemented through the Large-Scale Social Collaboration Program/ Kolaborasi Sosial Berskala Besar (KSBB) which was ratified by Governor Regulation Number 24 of 2020 concerning the Jakarta Development Collaboration Network. The KSBB program was introduced by The Jakarta Governor through his Instagram account @aniesbaswedan which contained an invitation to collaborate with the community in helping others in need from May 1, 2020. KSBB Program can be accessed openly through the official website corona.jakarta.go.id/ksbb. The site, which contains information regarding the number of Rukun Warga (RW), orphanages, nursing homes, disabled homes, and Islamic boarding schools as the target group for this program, is also accompanied by a map of the KSBB. Following KSBB, procedures for donating in this program, could be traced by suara.com [20]:

1) Determine the Location / Place of Donation Distribution. The first step requires selecting the area to which the prospective collaborator wants to channel donations through the platform provided. This platform contains information related to the selected area, as well as the number of Family Heads (KK) in it.

2) Determine the assistance package. There are four (4) package options available. The forms of assistance donated ranged from ready-to-eat packages worth IDR 45,000 to food packages worth IDR 200,000. The form of assistance donated was also provided an Eid al-Fitr package worth Rp. 85,000 and a cash THR package of Rp. 50,000.

3) Complete collaboration commitment form. Prospective collaborators should complete a commitment form for aid package distribution. This form contains a summary of the target area and the selected assistance package.

4) Coordination and distribution of aid. After filling out the collaboration commitment form, prospective collaborators will get related party contacts to help with the donation distribution process.

Collaboration with social organizations are shown as aid distribution activities that are carried out in coordination and engagement with the DKI Jakarta Red Cross, DKI Jakarta Baznas Bazis, Rumah Zakat Foundation, Aksi Cepat Tanggap, Human Initiative and Dompet Dhuafa. Within 14 days since KSBB announced, it has collected collaborative commitments of 209,381 food packages, 87,050 ready-to-eat packages, 
14,456 Eid packages, and 511 THR (14/5/2020). The aid package is then distributed to vulnerable people who are economically affected at the RW level. A total of 84 RWs from a total of 165 RWs have fulfilled their needs.

The aid packages distributed come from various collaborators who have joined the KSBB Program, ranging from individuals, groups to companies. There have been accumulated as many as 5 individual donors, as well as 51 collaborating organizations and companies, such as the DKI Jakarta Indonesian Museum Association, BPJS Ketenagakerjaan, Tokopedia, Lippo Karawaci, JNE, Rumah Yatim, PMI DKI Jakarta, YPO Satu Hati, Al Maghfirah Foundation. Bank DKI for example in 18 days, has provided donations of Rp1.1 billion. People engagement through Jakarta Government collaboration has increased more parties who join the KSBB Program, meaning the more people will be helped and their daily needs are fulfilled [20].

\section{B. Establishing Multi Stakeholders Partnership}

Partnership and collaboration in decision making to prevent and cope the pandemic has been done widely. Without collaboration with stakeholders, all the decisions will just go nowhere. Having the Private sector to close its business during the pandemic must be difficult that could cost more jobless and economic upside. Having religious leaders concerned about prohibiting prayer in masjid will be a lot more difficult but the argument to save lives is more important than all masjid and other religious buildings are close for public attending. Including collaboration with the central government that most of the time the policy concerns more to economic continuity rather than health and death issues (see table 1).

TABLE I. DKI JAKARTA STAKEHOLDERS PARTNERSHIP

\begin{tabular}{|c|l|l|}
\hline No & Partnership & \multicolumn{1}{c|}{ Result } \\
\hline 1 & $\begin{array}{l}\text { Health Center } \\
\text { DKI and } \\
\text { National Health } \\
\begin{array}{l}\text { Department. } \\
\text { Jan 22-24, 2020 }\end{array}\end{array}$ & $\begin{array}{l}\text { lacement of thermal scanners at national } \\
\text { strengthening cooperation with the Ministry of } \\
\text { entrances such as airports and ports and the } \\
\text { provision of personal protective equipment } \\
\text { (PPE) according to standards. } \\
\text { released the Health Office Circular No. 21 of } \\
\text { 2020 contains recommendations for precautions } \\
\text { including socialization of symptoms to } \\
\text { recommendations for hygienic life. }\end{array}$ \\
\hline 2 & $\begin{array}{l}\text { All DKI Jakarta } \\
\text { Stakeholders } \\
\text { Feb 28,2020 }\end{array}$ & $\begin{array}{l}\text { instructed all levels of the Provincial } \\
\text { Government to start taking steps to prevent the } \\
\text { transmission of COVID-19 (Coronavirus } \\
\text { Disease 2019). linsted in } \\
\text { The instructions given are also listed } \\
\text { Governor Instruction No. 16 of 2020. }\end{array}$ \\
\hline
\end{tabular}

Table 1. Cont

\begin{tabular}{|c|c|c|}
\hline 3 & $\begin{array}{l}\text { Health Center, } \\
\text { Major, } \\
\text { Subdistrict, } \\
\text { Citizen } \\
\text { Organization } \\
\text { Mar 2, } 2020\end{array}$ & $\begin{array}{l}\text { DKI Jakarta Provincial Government Forms } \\
\text { COVID-19 Response Team to improve } \\
\text { monitoring and supervision, also committed to } \\
\text { the openness of the government in every step to } \\
\text { prevent the corona outbreak. }\end{array}$ \\
\hline 4 & $\begin{array}{l}\text { IT and Digital } \\
\text { Stakeholders } \\
\text { Mar 6, } 2020\end{array}$ & $\begin{array}{l}\text { Web corona.jakarta.go.id established to have an } \\
\text { official information on coronavirus spread and } \\
\text { government health program }\end{array}$ \\
\hline 5 & $\begin{array}{l}\text { Business and } \\
\text { Society } \\
\text { Mar } 11,2020\end{array}$ & Car Free day is off \\
\hline 6 & $\begin{array}{l}\text { Schools and } \\
\text { Universities } \\
\text { Mar 14, } 2020\end{array}$ & $\begin{array}{l}\text { The DKI Jakarta Education Agency (Disdik) } \\
\text { also released Circular No. } 32 \text { of } 2020 \\
\text { concerning Home Learning in the Emergency } \\
\text { of COVID- } 19 \text {. }\end{array}$ \\
\hline 7 & $\begin{array}{l}\text { Transportation } \\
\text { Stakeholders } \\
\text { Mar } 15,2020\end{array}$ & $\begin{array}{l}\text { DKI Jakarta Provincial Government has } \\
\text { modified a number of public transportation } \\
\text { services, including Moda Raya Terpadu } \\
\text { (MRT), Lintas Raya Terpadu (LRT), and } \\
\text { Transjakarta. limiting routes as well as } \\
\text { passenger capacity to allow the implementation } \\
\text { of social distancing rules. }\end{array}$ \\
\hline 8 & $\begin{array}{l}\text { Religious } \\
\text { Leaders and } \\
\text { Organizations } \\
\text { Mar 19, } 2020\end{array}$ & $\begin{array}{l}\text { Provincial Government to prevent crowds amid } \\
\text { the pandemic is to temporarily suspend } \\
\text { religious activities in houses of worship. }\end{array}$ \\
\hline 9 & $\begin{array}{l}\text { Public and Non } \\
\text { Public Offices, } \\
\text { Tourisms } \\
\text { Industry } \\
\text { Mar 20, } 2020\end{array}$ & $\begin{array}{l}\text { Governor's Appeal No. } 6 \text { of } 2020 \text { concerning } \\
\text { the Temporary Cessation of Office Activities } \\
\text { a number of entertainment and tourist spots } \\
\text { crowded locations were also closed }\end{array}$ \\
\hline 10 & $\begin{array}{l}\text { Public, Private, } \\
\text { Society } \\
\text { April 9, } 2020\end{array}$ & $\begin{array}{l}\text { Governor Regulation No. } 33 \text { of } 2020 \text {, } \\
\text { inaugurated the implementation of large-scale } \\
\text { social restrictions in Jakarta. } \\
\text { The government also provides exemptions to } \\
11 \text { sectors that are allowed to continue } \\
\text { operating, including health, communications } \\
\text { and finance. }\end{array}$ \\
\hline 11 & $\begin{array}{l}\text { NGOs, Civil } \\
\text { Society, Group } \\
\text { of Society } \\
\text { April 16, } 2020\end{array}$ & $\begin{array}{l}\text { Governor Decree No. } 386 \text { of } 2020 \text { concerning } \\
\text { the provision of social assistance to } 1,194,633 \\
\text { heads of families who had difficulty meeting } \\
\text { basic needs during the PSBB period. }\end{array}$ \\
\hline 12 & $\begin{array}{l}\text { Private, Social } \\
\text { Organiza-tion } \\
\text { April 30,2020 }\end{array}$ & $\begin{array}{l}\text { DKI Pemprov Launches Large-Scale Social } \\
\text { Collaboration (KSBB) }\end{array}$ \\
\hline 13 & $\begin{array}{l}\text { Society and } \\
\text { social organiza- } \\
\text { tion } \\
\text { May } 5,2020\end{array}$ & $\begin{array}{l}\text { Collaboration programs managed by the JDCN } \\
\text { network, residents can contribute as volunteers } \\
\text { or donate equipment needed by medical } \\
\text { personnel to fight the corona outbreak. }\end{array}$ \\
\hline
\end{tabular}


Table 1. Cont.

\begin{tabular}{|l|l|l|}
\hline 14 & $\begin{array}{l}\text { Civil Society, } \\
\text { religious leader } \\
\text { and } \\
\text { organization, } \\
\begin{array}{l}\text { Public and Non } \\
\text { Public Office, } \\
\text { Security } \\
\text { May 17,2020 }\end{array}\end{array}$ & $\begin{array}{l}\text { Appeal to residents not to go home on IdulFitri } \\
\text { The government also regulates entry and exit } \\
\text { permits for the Jakarta area through an exit- } \\
\text { entry permit (SIKM). }\end{array}$ \\
\hline 15 & $\begin{array}{l}\text { Islamic } \\
\text { Organization, } \\
\text { Mesjid,Leaders } \\
\text { May 19 }\end{array}$ & $\begin{array}{l}\text { Guidelines for Takbir and Eid Prayers during } \\
\text { the Covid-19 Period. } \\
\text { The DKI Jakarta Provincial Government has } \\
\text { appealed to Muslims in the Capital City not to } \\
\text { hold Eid prayers in congregation in mosques or } \\
\text { in the field. The Indonesian Ulema Council has } \\
\text { also allowed the implementation of Eid prayers } \\
\text { at home through the issuance of fatwas and } \\
\text { guidance on takbir and Eid prayers in the midst } \\
\text { of a pandemic. }\end{array}$ \\
\hline
\end{tabular}

Source: https://smartcity.jakarta.go.id/blog/507/linimasa-kebijakan-penanganan-pandemi-covid-

19-di-jakarta.

Even though Government Jakarta has done all possible ways to protect its citizens, by September 11, the number of infected cases and deaths increased. This is not only because Jakarta is the capital of Indonesia, the door of any foreign and international program also the capital with a 12 million population find it difficult to extend its policy to close their border to save its region at an earlier step as should be.

\section{Accelerating Implementation of innovative Digital Technologies}

DKI Jakarta is a province that is quite responsive in facing Covid-19. DKI has an official website corona.jakarta.go.id. The website has quite complete information regarding Covid 19 starting from case information. Before the Covid-19 Pandemic hit the whole world, DKI already had an application called JAKI (Jakarta Terkini), in this application there were various features including JakWarta, JakLapor, JakPangan, JakRespons, JakPantau, JakAman, JakWifi, JakSiaga, JakISPU, JakSurvei, JakApps, JakCo, and Traces. In tackling covid, the features in the existing application have been modified so that they can help in overcoming covid-19 in DKI Jakarta.

JakWarta displays the latest information related to Covid 19 , such as the release of brief updates on COVID-19 case data every day, starting from the cumulative number of positive cases, in treatment, independent isolation, patients declared cured, and patients who died. JakWarta also contains news articles on handling COVID-19 in the capital, sourced from beritajakarta.id.

There is also a JakLapor feature which can help users to report if they still see that there are still people who do not comply with health protocols, for example, still crowding around. The report will be received, then the DKI Jakarta Provincial Government's Rapid Community Response (CRM) system will initiate a coordination process with local officials for dissolution. In addition, officers will also provide socialization to residents about the importance of staying at home during the corona pandemic.

Apart from JakWarta and JakLapor, the JakPangan feature also assists in fulfilling the needs of the related communities. because they are required to stay at home, the JakPangan feature can help users find out market prices, in addition, PD Pasar Jaya, which is a government-owned regional company, opens a service for ordering food needs from home, so that people do not need to come directly to the market, but they just need to be in touch with merchants by telephone. As for shipping, PD Pasar Jaya has also collaborated with online motorcycle taxi services. If you have questions, each market also includes a phone number that you can call. In dealing with covid-19, the JAKI application adds 2 new features, namely JakCLM and JakSekolahmu.

TABLE II. Digital TeChNOLOGIES For JAKARTA Fighting PANDEMIC COVID19

\begin{tabular}{|c|c|c|}
\hline No & $\begin{array}{c}\text { Digital } \\
\text { Program }\end{array}$ & Purposes \\
\hline 1 & $\begin{array}{l}\text { Corona } \\
\text { Likelihood } \\
\text { Metric } \\
\text { (CLM). } \\
\text { Focus: } \\
\text { Risk of } \\
\text { covid } \\
\text { identifica- } \\
\text { tion }\end{array}$ & $\begin{array}{l}\text { A self-contained testing or screening application with } \\
\text { machine learning technology to to assist one in } \\
\text { measuring risk of being positive for Covid-19 and } \\
\text { recommending what one should do. } \\
\text { The process of building this CLM engine with data } \\
\text { preprocessing, namely by cleaning existing data so } \\
\text { that it is ready to be studied by our machine learning } \\
\text { model. } \\
\text { It builds multiple versions of the machine learning } \\
\text { model with } 80 \% \text { of the data at hand. It tested the } \\
\text { performance of these models using several criteria, } \\
\text { namely accuracy, precision, and sensitivity using } \\
20 \% \text { of the testing data. } \\
\text { The model with the best performance is then } \\
\text { evaluated for this CLM machine, which the public } \\
\text { can then use to find out more about the positive risk } \\
\text { percentage for Covid-19. }\end{array}$ \\
\hline 2 & $\begin{array}{l}\text { Artificial } \\
\text { Intelli- } \\
\text { gence } \\
\text { Focus: } \\
\text { Monitoring } \\
\text { System }\end{array}$ & $\begin{array}{l}\text { Working with Nodeflux to build a monitoring system } \\
\text { using Artificial Intelligence (AI); detect and } \\
\text { calculate the density of people and vehicles (Public } \\
\text { Mobility Monitoring), monitor and give warnings } \\
\text { automatically when the distance between humans is } \\
\text { less than } 1 \text { meter (Social Distance Monitoring), and } \\
\text { monitor and give warnings automatically when there } \\
\text { are residents who are not wearing a mask (Face Mask } \\
\text { Monitoring) }\end{array}$ \\
\hline 3 & $\begin{array}{l}\text { Jejak } \\
\text { Focus: } \\
\text { Monitoring } \\
\text { System } \\
\end{array}$ & $\begin{array}{l}\text { to scan individual movements via QR code, the } \\
\text { technology will provide an overview of the location } \\
\text { of the movement of positive Covid } 19 \text { patients for } 14 \\
\text { days. This technology can also aid contact tracing }\end{array}$ \\
\hline 4 & $\begin{array}{l}\text { sekolah.mu } \\
\text { Focus: } \\
\text { Students }\end{array}$ & $\begin{array}{l}\text { it provides information online for student related } \\
\text { prominem program on book story, knowledge and } \\
\text { sciences, Covid-19 information }\end{array}$ \\
\hline 5 & $\begin{array}{l}\text { Jakarta } \\
\text { Aman } \\
\text { Focus: } \\
\text { citizen }\end{array}$ & $\begin{array}{l}\text { application to report emergencies that integrated with } \\
\text { security officers, citizens could contact any } \\
\text { endangered issues such as fire,accidents, criminals. } \\
\text { Including the spread of covid } 19\end{array}$ \\
\hline
\end{tabular}

source: smartcity.jakarta.go.id.

The table 2 showed that applying digital technology has been implemented in order to save more people from the pandemic sphere. Unfortunately those digital technologies that 
make citizens protect themselves in earlier prevention from Covid19 seems not be widely known by lower level income and education in Jakarta. All these five IT based services to handle covid has been so far considered further modernized in tackling covid 10. Further before Covid 19, public services using IT have also been applied as mentioned in Table 3. It has made public services easier, cheaper and shorten the time.

TABLE III. DigITAl PUblic SERVICES PROVIDED Before THE PANDEMIC COVID-19 DKI JAKARTA

\begin{tabular}{|c|c|c|}
\hline No & $\begin{array}{c}\text { Digital } \\
\text { Program }\end{array}$ & Purposes \\
\hline 1. & $\begin{array}{l}\text { Alpukat } \\
\text { Betawi } \\
\text { Focus: } \\
\text { Demography }\end{array}$ & $\begin{array}{l}\text { This application from the Jakarta Population and } \\
\text { Civil Registry Office is used to take care of all } \\
\text { matters related to civil documents such as KTP, } \\
\text { birth certificate, family card, and children's } \\
\text { identity card. To register, users must prepare } \\
\text { personal data such as name, KTP, Family Card, } \\
\text { email address, and phone number that can be } \\
\text { contacted. }\end{array}$ \\
\hline 2 & $\begin{array}{l}\text { PTSP DKI } \\
\text { Jakarta } \\
\text { Focus: } \\
\text { Public Service }\end{array}$ & $\begin{array}{l}\text { One Stop Integrated Service or shortened to PTSP } \\
\text { is a service from the DKI Jakarta Provincial } \\
\text { Government for matters relating to licensing and } \\
\text { non-licensing. }\end{array}$ \\
\hline 3 & $\begin{array}{l}\text { Pajak Online } \\
\text { DKI Jakarta } \\
\text { Focus: } \\
\text { Tax }\end{array}$ & online tax payment application \\
\hline 4 & $\begin{array}{l}\text { Ijakarta } \\
\text { Focus: } \\
\text { Online } \\
\text { Library }\end{array}$ & $\begin{array}{l}\text { An online library that provides thousands of books } \\
\text { to read. This application is also equipped with } \\
\text { other excellent features such as e-libraries, feeds, } \\
\text { virtual bookshelves, and eReaders. }\end{array}$ \\
\hline 5 & $\begin{array}{l}\text { Jak Evo } \\
\text { Focus: } \\
\text { Licensing }\end{array}$ & $\begin{array}{l}\text { application for selling applications for trade } \\
\text { business permits (SIUP) or company registration } \\
\text { certificates (TDP). }\end{array}$ \\
\hline 6 & $\begin{array}{l}\text { PPID } \\
\text { Focus: } \\
\text { Transpa-rency } \\
\text { of information }\end{array}$ & $\begin{array}{l}\text { As a form of information disclosure, the } \\
\text { Provincial Government of DKI Jakarta has } \\
\text { established an Information and Documentation } \\
\text { Management Officer (PPID). On the official } \\
\text { website, users can search and find a number of } \\
\text { public information, such as follow-up reports on } \\
\text { community reports throughout the year. }\end{array}$ \\
\hline 7 & $\begin{array}{l}\text { e-Musrenbang } \\
\text { Focus: } \\
\text { Accommo- } \\
\text { dating public } \\
\text { spirations }\end{array}$ & $\begin{array}{l}\text { This application is a container for community } \\
\text { aspirations and suggestions related to development }\end{array}$ \\
\hline 8 & $\begin{array}{l}\text { JAIS } \\
\text { Focus: } \\
\text { Pets } \\
\text { animal and }\end{array}$ & $\begin{array}{l}\text { The DKI Jakarta Provincial Government launched } \\
\text { the Jakarta Animal Identification System (JAIS) } \\
\text { application as a form of government concern for } \\
\text { the health of pets and other animals }\end{array}$ \\
\hline 9 & $\begin{array}{l}\text { JAKI } \\
\text { Focus: } \\
\text { Answer the } \\
\text { needs } \\
\text { society }\end{array}$ & $\begin{array}{l}\text { An application made to answer the needs of the } \\
\text { capital city community, from reporting violations } \\
\text { to information on food prices needs of the capital } \\
\text { city community, from reporting violations to } \\
\text { information on food prices }\end{array}$ \\
\hline 10 & $\begin{array}{l}\text { Pantau Banjir } \\
\text { Focus: } \\
\text { Flood monitor }\end{array}$ & $\begin{array}{l}\text { This application is made to monitor the condition } \\
\text { of the water pump and the water level at the user's } \\
\text { closest observation post and floodgate, so that the } \\
\text { user knows whether the area will be flooded or } \\
\text { not. }\end{array}$ \\
\hline
\end{tabular}

source: https://corona.jakarta.go.id/id/artikel/mengenal-layanan-pemerintah-jakarta-yang-sudah-
As capital of Indonesia, there is no doubt that Jakarta is more advanced compared to other provinces in Indonesia. Beside it has the highest Local Revenue, the position of being Indonesia capital has changed a lot in communication Internationally and locally.

\section{DISCUSSION}

During the hit of pandemic Covid-19, Jakarta as epicentrum has been struggling from earlier January to call for awareness to minimize cases and death by consulting all the health facilities in Jakarta as well as coordinating with the National Health Department. However, many of those policies and actions to prevent the virus spread further need to have confirmation from the national level. Limitation for foreigners flows from the international airport seemingly with less cautions from the central government. Study from overseas health observation that the virus has been in Indonesia since January was ignored by elites instead of having a serious attention and call for earlier collaboration to cope the pandemic. Other developed countries as daily bases have been shown on TV how the deaths occurred without enough health facilities to cure.

Social accountability in this situation is very important in which citizen monitoring and oversight of public and/or private sector performance, user-centered public information access/dissemination systems, public complaint and grievance redress mechanisms, as well as citizen participation in actual resource allocation decision-making, such as participatory budgeting. As the pandemic has spread tremendously, budget allocation and donation to help people the cure was announced. Even Though, it seems all the help to help economic impact instead of health facilities and medical attention, it is necessary to call for this social accountability.

\section{A. Engaging People}

The response to covid 19 cannot only be implemented by the government without community support. Accountability requires public participation on a strong spectrum to produce better public policies. The DKI Jakarta provincial government has created a program called Large-Scale Social Collaboration (KSBB) in DKI Jakarta. In this program, the DKI Jakarta government acts as a facilitator or channel of assistance from the community to the community. The government also collaborates with social organizations in managing assistance from the community for these communities, such as the Dompet Duafa Foundation, the Indonesian Red Cross, Baznas DKI Jakarta, Rumah Zakat, Aksi Cepat Tanggap, and the Human Initiative.

KSBB is divided into two types, namely KSBB Food and KSBB UMKM (Micro, Small and Medium Enterprises). KSBB Food is a collaboration program from the community for the community to provide ready-to-eat food or groceries for families affected by covid 19. while KSBB UMKM is a collaborative program from the community to help MSMEs affected by covid 19.There are 3 packages that can be selected 
if the community wants to help MSMEs including Facilities and Infrastructure Packages, Capital Loan Packages and Training Packages. DKI Jakarta is home to 1.1 million MSMEs that contribute to the economy and provide for the needs of the people of Jakarta as well as driving $94 \%$ of the city's economy. As shown in Graphic 1. a number of citizens have received social collaboration on a larger scale and have grown public trust.

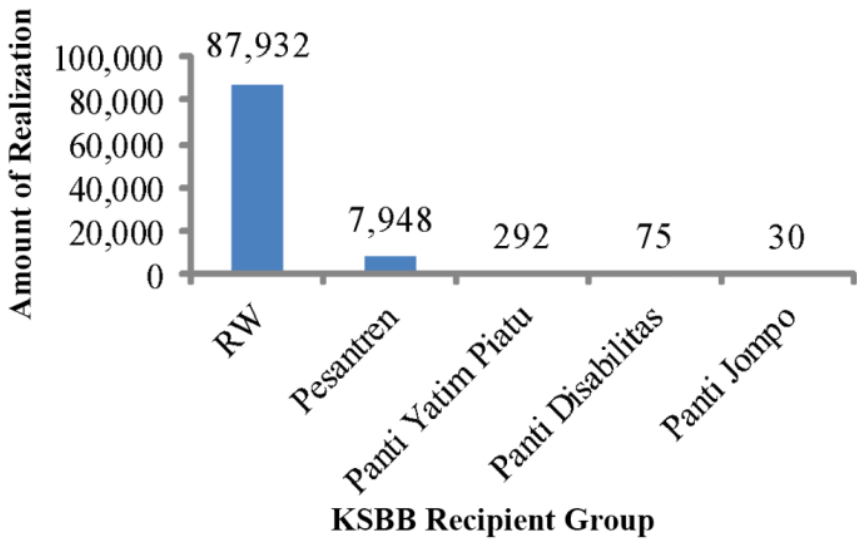

Fig. 1. Number of People/Citizens Organisation have received KSBB.

For transparency, the amount of aid received and donated has been uploaded on the website of the DKI Jakarta provincial government via corona.jakarta.go.id. This proves that the DKI Jakarta provincial government is very open in involving the community in overcoming covid 19 in DKI Jakarta. Transparency will encourage more organization and citizens to participate

The involvement of civil society organizations, the private sector, and the general public in the response to the COVID-19 pandemic has proven effective in several countries. Using media online and social media to show empathy and the need for social responsibility have encouraged more citizens to participate in helping other poor families and individuals that hit their life. other China and Korea involve various parties to find ways to carry out case tracing more quickly and accurately. As a result, Korea has successfully implemented case tracking using location data from cell phones, credit card transaction records, and CCTV footage, while China launched a City Health QR Code service through a government service platform.

The DKI Jakarta government is also collaborating with several pioneering companies to create new solutions to tackle Covid 19, including the Corona Likelihood Meter, and Artificial Intelligence to detect crowds and a history of community visits.

\section{B. Establishing Multi Stakeholders Partnership}

The Covid 19 pandemic that occurred certainly demands effective countermeasures from the government. However, the government often lacks the ability both in terms of funds and human resources to develop efficient and effective digital tools to answer the needs of overcoming covid 19. This limitation demands a partnership between the government and the private sector or social institutions.

So far, the DKI Jakarta Provincial Government has collaborated with various parties, both internal and external to the DKI Jakarta Provincial Government. To support collaboration, the Health Office (Dinkes) together with the DKI Jakarta Communication and Information Agency have built a special portal as a medium of communication between individuals, agencies, or institutions that wish to collaborate through the Jakarta Development Collaboration Network (JDCN).

Several startups have collaborated with the DKI Jakarta Health Office, including Telkomsel, Good Doctor, Halodoc, Docquity, Prosehat, and others. Telkomsel assists in providing hunting system services, devices, and free subscriptions to support the Dinkes Call Center services.

The DKI Jakarta Health Office also collaborates with Good Doctor and Halodoc in providing doctor consultation services, providing the latest information on COVID-19, and several matters related to DKI Jakarta policies through a chat doctor mechanism. In addition, Docquity also assists in holding Webinars for training processes for volunteers and Prosehat which provides chatbot services to provide more online consultations. Collaboration between the government and startups has helped ease the burden on health facilities and medical personnel, especially in reducing contact between medical personnel and people suspected of being sick [21].

Countries in the world that experienced the Covid 19 pandemic are also collaborating with various stakeholders. For example, the United States Government issued a call for action to key industry stakeholders and artificial intelligence experts to develop new text and data mining techniques that can help the scientific community answer high-priority questions related to COVID-19 [22]

\section{Accelerating Implementation of innovative Digital Technologies}

There is no other way to perform better in public services but applying innovative technology. As shown in table 3 , the government has implemented many IT develop applications to make sure the services delivered in a short time are easy for citizens. Form birth certificate application online, government services online, any related information as well as report for any condition that endanger the society life such as fire, floating and crime. Call center works 24 hour a day without holiday.

Working under a pandemic event hardly forced the government to work smart using technology. When social distancing and work from home were advised in any offices and citizens, IT based services are a must and a demand. Since March, at least 5 innovative digital technology has been 
applied to fasten tracking the virus and its implication. Table 2 has informed the information needed by online regarding the spread of Covid-19, for example a self-contained testing or screening application with machine learning technology to to assist one in measuring risk of being positive for Covid-19 and recommending what one should do. For student also information for their need to reduce stress and encouragement, for social collaboration by helping each other under coordination of government has also increased the care center for others.

\section{CONCLUSION}

Government should consider to save its citizen over economic concern. Jakarta has put effort to perform its responsibility despite of its lack communication with central government at the earlier stage. in addition, to cope with the economic problem, the government of jakarta has apply digital and social accountability. Three criterias to analyze social and digital accountability in tackling the pandemic covid-19 are engaging people, stakeholder partnership and innovative digital technology apparently have been implemented in Jakarta government. The government has earlier awareness of the pandemic and do some collaboration and communication to prevent the virus got larger infected in society. Those three indicators by using content analysis have actually fulfilled the necessary action to cope with the speed coronavirus.

However, the finding of this study that all efforts to prevent and accommodate any important policy and action are actually facing the authority of the provincial government to enact fast and firm. As capital as well as local government under deconcentration power by central government, it is clearly shown that local government can not do further without concern by central government. Having early action to implement limitations of foreigners' tourism and movement of people from and to Jakarta was not well responded by the central government. Central government concerns more to economic flows than virus attacks overwhelmingly. It is actually shown by other developed countries, Italy and USA that can not prevent the virus from hitting their countries even though they do have higher technology and healthcare facilities.

Lesson learnt can be concluded from this study that action to prevent pandemic virus should be fast and fully supported from central to local government. Having people engage, calling stakeholder cooperation and applying innovative digital technology seemingly only a supportive system to strengthen the authority action to put health concerns more important than economy circulation. There is no short term, middle term and long term sufficient planning from central government to local government in causing DKI Jakarta as the capital facing a tremendous difficult situation. One side that the Jakarta Government has to respond faster to social accountability demands and strengthened by digital accountability, another side that the authority to implement limitations and action on its policy was not equivalently coordinated and supported by the central government.

\section{REFERENCES}

[1] WHO .2020. WHO Director-General's opening remarks at the media briefing on COVID-19-11 March 2020: Accessed on 9 September 2020 from https://www.who.int/dg/speeches/detail/who-director-general-sopening-remarks-at-the-media-briefing-on-covid-19---11-march-2020

[2] WHO. 2020. WHO Coronavirus Disease (COVID-19) Dashboard Accessed on 9 September 2020 from https://covid19. who.int/table

[3] A. Jones, "Covid-19: Bagaimana cara Selandia Baru yang dengan keras dan sejak dini mengalahkan virus corona". 2020. Accessed on 9 September 2020 from https://www.bbc.com/indonesia/dunia-53359809

[4] A. M. Idhom, "Daftar Strategi Korea Selatan Redam Pandemi Corona versi Dubes". 2020 [Online] available from: https://tirto.id/daftarstrategi-korea-selatan-redam-pandemi-corona-versi-dubes-eLmB

[5] A. Ananda. 2020. Jurus Jokowi Lawan Virus Corona dengan Diskon Tiket Pesawat. Accessed on 9 September 2020 from https://www.cnnindonesia.com/ekonomi/20200226091352-532478192/jurus-jokowi-lawan-virus-corona-dengan-diskon-tiket-pesawat

[6] Detiknews.com, 2020. Nilai Pemerintah Remehkan Corona YLBHI Kontras Tuntut Penanganan Serius. Accessed on September 2020 from https://news.detik.com/berita/d-4937709/nilai-pemerintah-remehkancorona-ylbhi-kontras-tuntut-penanganan-serius

[7] Suara.com. 2020. Komunikasi Menkes Terawan di Kritik 4 Pernyataan Soal Corona Jadi Sorotan. Accessed on 4 September 2020 fromhttps://www.suara.com/news/2020/03/04/101853/komunikasimenkes-terawan-dikritik-4-pernyataan-soal-corona-jadi-sorotan?page=2

[8] Kompas.com.2020. Diumumkan Awal Maret, Ahli: Virus Corona Masuk Indonesia dari Januari. Accessed on 9 September 2020 from https://www.kompas.com/sains/read/2020/05/11/130600623/diumumkan -awal-maret-ahli--virus-corona-masuk-indonesia-dari-januari

[9] S. T. Aulia, Diskursus Penanganan Covid oleh Pemerintah Pusat dan Daerah: Efektifkah Kebijakan Pembatasan Sosial Berskala Besar (PSBB) diterapkan? Accessed on 7 September 2020 fromhttp://fh.unpad.ac.id/diskursus-penanganan-covid-19-olehpemerintah-pusat-dan-daerah-efektifkah-kebijakan-pembatasan-sosialberskala-besar-psbb-diterapkan/

[10] C. G. Asmara, "Maaf Pak Anies, Permintaan Lockdown DKI Ditolak Jokowi". 2020. Accessed on 10 September 2020 from https://www.cnbcindonesia.com/news/20200331085509-4148631/maaf-pak-anies-permintaan-lockdown-dki-ditolak-jokowi

[11] Covid.go.id. Update Laporan Kasus per 30 Agustus 2020

[12] Jakarta Smart City. 2020. Kolaborasi Jakarta dengan Stratup Menghadapi COVID-19. Accessed on 10 September 2020 fromhttps://smartcity.jakarta.go.id/blog/491/kolaborasi-jakarta-denganstartup-menghadapi-covid-19

[13] Indonesia Corruption Watch et al. 2020. The Accountability od Covid19 Pandemic Handling. Policy Brief

[14] Jelita Insi Nantika. 2020. Pengaduan Masalah Bansos terbanyak dari

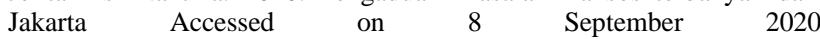
fromhttps://mediaindonesia.com/read/detail/313014-pengaduanmasalah-bansos-terbanyak-dari-jakarta

[15] Cnnindonesia. 2020. ICW Terima 12 Laporan Soal Bansos DKI Tahap 3-4 Accessed on 1 September 2020 fromhttps://www.cnnindonesia.com/nasional/20200828022835-20540152/icw-terima-12-laporan-soal-bansos-dki-tahap-3-4

[16] Virginia Wilson. 2011. Evidence Based Library and Information Practice.

[17] Terry College of Business University of Georgia. Research and Methodology. https://www.terry.uga.edu/contentanalysis/research-andmethodology.php

[18] Kompas.com. Perjalanan PSBB Transisi di Jakarta Hingga Anies Tarik Rem Darurat. Accessed on 12 September 2020 from https://www.kompas.com/tren/read/2020/09/11/190300865/perjalananpsbb-transisi-di-jakarta-hingga-anies-tarik-rem-darurat-?page $=$ all 
[19] Bebas kompas.id. Partisipasi Publik Menghadapi Covid 19 Accessed on 12 September 2020 from https://bebas.kompas.id/baca/riset/2020/04/21/partisipasi-publikmenghadapi-covid-19/

[20] Suara.com. Program Bahu Membahu Anies dalam Membantu Masyarakat Terdampak Covid Accessed on 12 September2020 from https://www.suara.com/yoursay/2020/05/29/152920/program-bahumembahu-ala-anies-dalam-membantu-masyarakat-terdampakcovid?page=all
[21] Jakarta Smart City. Ngobrol Jakarta 16 Lawan Pandemi Covid 19 dengan Kolaborasi. Accessed on 12 September 2020 from https://smartcity.jakarta.go.id/blog/484/ngobrol-jakarta-16-lawanpandemi-covid-19-dengan-berkolaborasi

[22] UNDP. Covid-19: Embracing digital government during the pandemic and beyond. United Nations Departement of Economic and Social Affairs. Policy Brief No. 61 